\title{
Biological Treatment of Reactive Black 5 by Resupinate White Rot Fungus Phanerochaete sordida PBU 0057
}

\author{
Ponlada Permpornsakul ${ }^{1,2}$, Sehanat Prasongsuk ${ }^{2 * *}$, Pongtharin Lotrakul ${ }^{2}$, \\ Douglas E. Eveleigh ${ }^{3}$, Donald Y. Kobayashi ${ }^{4}$, Tsuyoshi Imai ${ }^{5}$, Hunsa Punnapayak ${ }^{2 *}$ \\ 'Biological Science Program, Faculty of Science, Chulalongkorn University, Bangkok 10330, Thailand \\ ${ }^{2}$ Plant Biomass Utilization Research Unit, Department of Botany, Faculty of Science, \\ Chulalongkorn University, Bangkok 10330, Thailand \\ ${ }^{3}$ Department of Biochemistry and Microbiology, School of Environmental and Biological Science, \\ Rutgers University, New Brunswick, New Jersey 08901, USA \\ ${ }^{4}$ Department of Plant Biology and Pathology, School of Environmental and Biological Science, \\ Rutgers University, New Brunswick, New Jersey 08901, USA \\ ${ }^{5}$ Division of Environmental Science and Engineering, Graduate School of Science and Engineering, \\ Yamaguchi University, Ube, Yamaguchi, 755-8611, Japan
}

Received: 28 December 2015

Accepted: 29 January 2016

\begin{abstract}
Resupinate white rot fungi were isolated from across Thailand (seven provinces) and evaluated for their ability to degrade the recalcitrant and toxic dye reactive black 5 (RB5). Seven of the 13 isolates decolorized RB5 (100 mg/L) within three days (greater than 50\%). One isolate, Phanerochaete sordida PBU 0057, yielded complete decoloration within three days. It was active under environmental conditions in which waste dyes are discharged. The degradation of RB5 by P. sordida PBU 0057 was confirmed by spectrophotometric and HPLC analyses. The degradation was associated with the activities of laccase and lignin peroxidase. Manganese peroxidase was additionally active in the comparative control strain of P. chrysosporium. The degradation dye products produced by $P$. sordida $\mathrm{PBU} 0057$ were not phytotoxic towards Phaseolus vulgaris, Sorghum bipolar, and Zea mays. Overall, P. sordida PBU 0057 showed somewhat greater dye-degradative activities when compared to the control reference strain P. chrysosporium ATCC 24725 under practical environmental conditions. P. sordida PBU 0057 has potential for application in the biological detoxification treatment of waste dye residues.
\end{abstract}

Keywords: azo dyes, lignin-modifying enzymes, Phaenerochaete chrysosporium, phytoxicity, resupinate fungi.

*e-mail: phunsa@chula.ac.th

** e-mail: sehanat.p@chula.ac.th 


\section{Introduction}

Synthetic dyes are in wide use by textile, paper, cosmetics, food, and pharmaceutical industries due to their low cost, their range of shades and brilliant colors, and practical properties including water solubility and high stability $[1,2]$. More than 10,000 synthetic dyes are in common use totaling around 700,000 metric tons annual production [3]. Unfortunately the most common group, the azo-dyes, can be toxic to plants and carcinogenic in animals [4]. The health safety issues are amplified as their breakdown products include mutagenic sulfonates and amines $[5,6]$. The discharge of such waste colorants into the environment poses serious pollution risks.

The structures and compositions of azo dye waste depends on the dyeing process [7]. Almost 20-50\% of the dyes can be lost during the dyeing process, thus resulting in dye residue concentrations of up to 100$200 \mathrm{mg} / \mathrm{L}$ in wastewaters [7]. In tropical countries, the discharge effluents can be warm (up to $30^{\circ} \mathrm{C}$ ) and are usually neutral to alkaline [8]. To alleviate environmental health and toxicity concerns, dye processing wastewaters require treatment systems that efficiently remove the toxic residues, which are functional in relatively broad environmental conditions $[7,8]$. The reduction of azo dye waste levels has been achieved by physicochemical approaches, including flotation, ozonation, and adsorption $[4,7,8]$. Microbial degradation systems are a further efficient and eco-friendly option [8-11].

Among biological dye treatments, the use of white rot fungi offers one of the most promising approaches based on the degradative action of their extracellular ligninmodifying enzymes (LMEs), including lignin peroxidase, manganese peroxidases, and laccase [9-12]. These enzymes can lead to complete mineralization of aromatic recalcitrant structures [8, 12, 13]. Furthermore, white rot fungi can tolerate a broad range of environmental conditions including high concentrations of toxic compounds, low $\mathrm{pH}$, and higher temperature [10, 11], making their potential application for wastewater treatment more attractive and practical.

Resupinate white rot fungi belong to the Aphyllophorales, or non-gilled mushrooms that have a flattened fruiting body adpressed to the substrate [14, 15]. Though similar in gross morphology, they have diverse anatomical, physiological, and molecular biological characteristics [15]. Phanerochaete chrysosporium is the most extensively studied white rot fungus due to its efficiency in attacking a range of condensed aromatic pollutants and lignin [16-19]. Broader studies of this resupinate group address their biodegradative capabilities [10], and specific focus has centered on Dichomitus squalens, Irpex lacteus, and Bjerkandera adusta [2, 20-22]. Resupinate white rots occur widely in tropical countries, including Thailand [23-25], and although their wood degradation was considered [26], their potential role in bioremediation has yet to be fully addressed.

This study addresses the decoloration capability of Thai resupinate fungi acting toward the most commonly used commercial azo dye, reactive black 5 (RB5). Resupinate fungi were isolated from seven Thai provinces. They were identified and screened for their production of LMEs and capability to decolorize RB5. The most efficient was an isolate of Phanerochaete sordida. It was compared with the white rot model species $P$. chrysosporium $[13,16]$. The decomposition of RB5 was evaluated under a range of physicochemical parameters. The biodegradation products were assessed using spectrophotometry and HPLC, and their toxicity was determined by phytotoxicity testing.

\section{Materials and Methods}

\section{Fungal Cultures}

Thirteen isolates of Thai resupinate fungi (Table 1) were isolated from naturally occurring fructifications through plating on selective media of $2 \%$ malt extract agar (MEA; Becton-Dickinson, USA) supplemented with the restrictors rose bengal (100 ppm, Sigma-Aldrich, USA) and benomyl (100 ppm, Benlate, E.I. Dupont Nemours, Inc., USA). The medium was autoclaved at $121^{\circ} \mathrm{C}$ for 15 min and cooled to $50^{\circ} \mathrm{C}$ prior to adding sterile filtration of chloramphenicol solution (100 ppm, Sigma-Aldrich, USA). Cultures were maintained on malt extract agar $(1.5 \% \mathrm{w} / \mathrm{v})$, stored at $4^{\circ} \mathrm{C}$, and subcultured monthly. They were deposited in the culture collection of the Plant Biomass Utilization Research Unit, Chulalongkorn University (PBU). Phanerochaete chrysosporium ATCC 24725, the model for lignin degradation studies, was used as a comparative reference culture.

\section{Fungal Identification}

Resupinate fungi were identified based on morphology and confirmed by their internal transcribed spacer (ITS) sequences.

\section{Morphological Identification}

Macroscopic morphological details of fresh specimens such as color, texture, and shape were recorded. Microscopic characteristics were observed from rehydrated sections of fruiting body mounted in $\mathrm{KOH}(5 \%)$ and stained with phloxine (1\%), cotton blue, sulphoaldehyde, and Melzer's reagent [27]. The general morphology and detailed anatomical features of specific elements included basidiospores, hyphae, cystedia, and the organization of the fruiting bodies used for identification included hymenium surface, shape of the basidia, and cystedia [27].

\section{ITS Sequencing}

To determine ITS sequences the cultures were grown on top of cellophane placed on 1.5\% MEA and harvested after seven days of culture. Genomic DNA was isolated by standard phenol-chloroform extraction [28]. Polymerase 
Table 1. Thai resupinate fungal isolates and their decoloration of RB5 dye.

\begin{tabular}{|c|c|c|c|c|c|c|c|}
\hline \multirow[b]{2}{*}{ No. } & \multirow[b]{2}{*}{ Fungal strain name } & \multirow{2}{*}{$\begin{array}{l}\text { Collection site } \\
\text { (Province) }\end{array}$} & \multirow{2}{*}{$\begin{array}{c}\text { GenBank } \\
\text { Accession No. } \\
\text { (ITS) }\end{array}$} & \multicolumn{3}{|c|}{ Enzyme productivity* } & \multirow{2}{*}{$\begin{array}{l}\text { Decoloration } \\
(\%)^{* *}\end{array}$} \\
\hline & & & & $\begin{array}{c}\text { Lignin } \\
\text { peroxidase }\end{array}$ & $\begin{array}{c}\text { Manganese } \\
\text { peroxidase }\end{array}$ & Laccase & \\
\hline 1 & Bjerkandera adusta PBU 0047 & Nan & KC570338 & + & ++ & + & ND \\
\hline 2 & Ceriporia cystidiata PBU 0048 & Roi Et & KC570339 & - & + & ++ & ND \\
\hline 3 & Irpex lacteus PBU 0049 & Kanchanaburi & KC570335 & ++ & ++ & + & 79 \\
\hline 4 & $\begin{array}{c}\text { Junghuhnia crustacea } \\
\text { PBU } 0050\end{array}$ & Kanchanaburi & KC570333 & ++ & + & ++ & 43 \\
\hline 5 & $\begin{array}{c}\text { Macrohyporia dictyopora } \\
\text { PBU } 0051\end{array}$ & Kanchanaburi & KC570331 & ++ & + & + & 61 \\
\hline 6 & Macrohyporia sp.PBU 0052 & Kanchanaburi & KC570332 & - & + & ++ & ND \\
\hline 7 & $\begin{array}{c}\text { Perenniporia tephropora } \\
\text { PBU } 0053 \\
\end{array}$ & Nakhon Ratchasima & KC570341 & - & ++ & +++ & ND \\
\hline 8 & $\begin{array}{c}\text { Perenniporia tephropora } \\
\text { PBU } 0054\end{array}$ & Nakhon Ratchasima & KC570342 & - & ++ & +++ & ND \\
\hline 9 & Perenniporia sp. PBU 0055 & Chonburi & KC570336 & - & + & +++ & ND \\
\hline 10 & $\begin{array}{c}\text { Phanerochaete sordida } \\
\text { PBU } 0057 \\
\end{array}$ & Nakhon Ratchasima & KC570340 & +++ & - & ++ & 100 \\
\hline 11 & Phanerochaete sp. PBU 0056 & Bangkok & KC570330 & ++ & + & + & 63 \\
\hline 12 & Phanerochaete sp. PBU 0058 & Chonburi & KC570337 & ++ & + & - & 59 \\
\hline 13 & Phanerochaete sp. PBU 0059 & Kanchanaburi & KC570334 & ++ & - & + & 48 \\
\hline
\end{tabular}

* Intensity and/or diameter ratio of activity zone and mycelial zone (+), lack of activity (-).

** The RB5 decoloration percentages in liquid medium on day 3: ND (Not determined in liquid media in that the dye color was not markedly reduced on agar plates after five days).

chain reactions were performed using ITS4 and ITS5 [29] and sent for sequencing (GENEWIZ DNA sequencing service, NJ). Each ITS sequence was assembled and analyzed using the DNAStar sequence analysis software (Lasergene) prior to submission to BLASTn search for comparison to those in the GenBank.

\section{Screening of Lignin-Modifying Enzyme Profiles in Agar Plates}

Lignin-modifying enzyme (LMEs) production was evaluated on LME basal medium (LMB) supplemented with $0.2 \%(\mathrm{w} / \mathrm{v})$ glucose and solidified with $1.6 \%(\mathrm{w} / \mathrm{v})$ agar [30]. Specific substrates included 2,2'-azino-bis (3-ethylbenzthiazoline-6-sulfonic acid (ABTS; SigmaAldrich, USA), azure-B (Sigma-Aldrich, USA) or phenol red (Sigma-Aldrich, USA)). Actively growing mycelial discs were used to inoculate the assay media in Petri dishes. ABTS $(0.1 \%)$ medium was used to detect laccase [31]. Formation of a green halo of oxidized ABTS around the fungal colony illustrated laccase production. Phenol red $(0.1 \%)$ medium was used to detect the ability to produce manganese peroxidase [32]. Change of phenol red color from yellow to red indicated the production of $\mathrm{Mn}^{3+}$. Changes in the intensity of discoloration were recorded as three categories, namely yellow $(+)$, orange $(++)$, and red $(+++)$. Azure B $(0.01 \%)$ plates were used to detect lig- nin peroxidase production [33]. Decoloration of azure B $(0.01 \%)$ - indicating a clear halo - was monitored daily. All plate assays were carried out at $30^{\circ} \mathrm{C}$ and in triplicate.

\section{Screening for RB5 Decoloration in Solid and Liquid Media}

For screening of RB5-decolorizing activity, mycelial discs (8 mm diam) were inoculated onto MEA containing RB5 (100 mg/L, Sigma-Aldrich, USA). The cultures were visually monitored daily for decoloration of the medium by the change from dark blue of RB5 to the slight yellow of MEA. Strains that decolorized the RB5 thoroughly on solid MEA within 5 days were subsequently tested for the ability to decolorize RB5 in liquid medium (modified malt extract broth) [34]. Two agar discs (8 mm diam) from the periphery of a five-day-old MEA colony were used to inoculate modified malt extract broth $(100 \mathrm{ml} /$ 250-ml Erlenmeyer flask), with incubation at $30^{\circ} \mathrm{C}$ under static conditions for three days. RB5 was sterilized by filtration (0.22- $\mu \mathrm{m}$; Millipore, Bedford, MA) and added to the culture at a final concentration of $100 \mathrm{mg} / \mathrm{L}$, with the $\mathrm{pH}$ adjusted to $\mathrm{pH} 7$. Incubation was continued with agitation at $150 \mathrm{rpm}$. Mycelia in the culture were separated by filtration through filter paper (Whatman No.1) and extracted with ethanol-water $(1: 1)$ for $1 \mathrm{~h}$ to desorb the dye [34]. The absorbance of residual RB5 was monitored 
at $597 \mathrm{~nm}$ using a Spectrophotometer (Unico, Specord 2000, Jena, Germany). All experiments were carried out in triplicate. Decoloration (\%) was based on:

\section{Decoloration $(\%)=[($ Initial Absorbance - Final Absorbance)/ Initial Absorbance] x 100}

... where Final Absorbance $=($ Mycelial free supernatant Mycelial desorbed solution).

\section{Effect of the Physicochemical Parameters for RB5 Decoloration}

The most efficient decolorizing isolate, $P$. sordida PBU 0057, was further evaluated in comparison to the reference strain $P$. chrysosporium. In relation to the effect of physicochemical parameters, the effects of $\mathrm{pH}(6,7$, and 8$)$, temperature $\left(25,30\right.$, and $\left.35^{\circ} \mathrm{C}\right)$, agitation $(0$ and $150 \mathrm{rpm})$, and RB5 concentration (100 and $200 \mathrm{mg} / \mathrm{L})$ were tested. Biotic and abiotic controls were carried out in parallel. The biotic controls included culture medium inoculated with fungus without dye; abiotic controls were culture medium supplemented with dye but lacking the fungus. The percentage of RB5 decoloration was monitored.

\section{Lignin-Modifying Enzyme Assays}

Lignin-modifying enzyme (LME) activities were determined spectrophotometrically using crude culture supernatant. Laccase activity was determined using ABTS as the substrate. The oxidation of ABTS was monitored at $30^{\circ} \mathrm{C}$ by measuring the increase in $\mathrm{A}_{420}$ $\left(\varepsilon=36.0 \mathrm{mM}^{-1} \mathrm{~cm}^{-1}\right)$. One $\mathrm{U}$ of laccase activity was defined as the amount of enzyme required to oxidize $1 \mu \mathrm{mol}$ of ABTS per minute [31]. Lignin peroxidase activity was measured by monitoring the oxidation of veratryl alcohol (Sigma-Aldrich, USA) to veratraldehyde at $310 \mathrm{~nm}$. One unit (U) of lignin peroxidase was defined as the amount of enzyme forming $1 \mu \mathrm{mol}$ veratraldehyde per minute $\left(\varepsilon=9.3 \mathrm{mM}^{-1} \mathrm{~cm}^{1}\right)[19]$. Manganese peroxidase activity was measured by monitoring the oxidation of 2 , 6-dimethoxyphenol (2, 6 DMP; Sigma-Aldrich, USA) at $469 \mathrm{~nm}\left(\varepsilon=27.5 \mathrm{mM}^{-1} \mathrm{~cm}^{-1}\right)$. One $\mathrm{U}$ of manganese peroxidase activity was defined as the amount of enzyme required to oxidize $1 \mu \mathrm{mol}$ of DMP per minute [35].

\section{Spectrophotometric and HPLC Assays}

Degradation of the dye was monitored spectrophotometrically from 400 to $700 \mathrm{~nm}$ [26], and by HPLC analysis [36]. The decolorized dye products were assessed by comparison of spectrophotometric peaks every 24 hours to those of RB5 (control). A progressive reduction in absorbance with time and lack of formation of new peaks indicated dye decoloration through cleavage of the chromophoric dye structure. HPLC analysis [36] of the decolorized dye products was performed using decolorized culture supernatants (initially $200 \mathrm{mg} / \mathrm{L} \mathrm{RB} 5$ ). The absence of a major dye peak and/or presence of new peaks at different retention times illustrated dye degradation [21]. The decolorized dye products were extracted from culture fluids (control and experimental samples) in methylene chloride $[21,36]$ passed over anhydrous sodium sulfate to remove water and evaporated to dryness in a rotary evaporator.

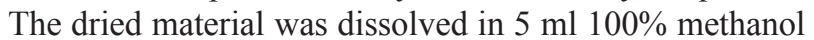
and subjected to HPLC (Lichospher, Germany) analysis on a reverse-phase $\mathrm{C} 18$ column (RP-C18 Phenomenex; $5 \mathrm{~mm}, 4.6 \mu \mathrm{m} \times 250 \mathrm{~mm})$ at $35^{\circ} \mathrm{C}$. The samples $(100 \mu \mathrm{l}$ loading) were analyzed using a gradient with $0.025 \mathrm{M}$ phosphate buffer $(\mathrm{pH} 3)$ and acetonitrile as the mobile phase from $10-90 \%$ [36]. The peaks were detected using a photo-diode detector at $254 \mathrm{~nm}$. The analyses were carried out in duplicate.

\section{Toxicity Test}

Phytotoxicity of the RB5 degradation products was assessed using azo dye-sensitive plants [5, 37]. Pesticidefree seeds, including sorghum (Sorghum bicolor Linn.), corn (Zea mays Linn.), and red kidney bean (Phaseolus vulgaris Linn.) were used. They were germinated in the presence of potential inhibitors at room temperature $\left(28 \pm 2^{\circ} \mathrm{C}\right)$ under a 12-hours light/12-hours dark cycle, and their percentage germination, shoot length, and root length were measured after incubation for seven days [38, 39]. Five replicates of three sets of samples were conducted, including one soaked with water, the second with RB5 $(200 \mathrm{mg} / \mathrm{L})$, and the third with biodegraded RB5 (200 mg/L).

\section{Results and Discussion}

\section{Collection and Isolation of Resupinate White Rot Fungi}

In the general isolation, resupinate fruiting bodies on wood were selected and 13 isolates were recovered (Table 1). The selection was from seven Thai provinces yielding an experimental group of isolates from across the country. Isolates represented seven genera, there being multiple isolates of Phanerochaete. This broad range of isolates was considered a practical representative group for the dye degradation studies. The LMEs associated with the degradation of the azo dyes were recorded. Twelve and 11 isolates were positive for laccase and manganese peroxidase activities, respectively, while only eight isolates produced lignin peroxidase (Table 1).

\section{Screening for Lignin-Modifying Enzymes}

The screening results revealed that lignin peroxidases, which is rarely found in typical white rot fungi [13], was relatively common among these resupinate fungi. Manganese peroxidase and laccase have previously been linked directly to the degradation of aromatic compounds, including decoloration of synthetic dyes by white rot 
fungi $[2,11,18,26]$. However, dyes containing highly recalcitrant structures could limit the decoloration ability of the fungus since they require higher redox potential of a catalyst to initiate electron distribution in a degradation mechanism $[6,16,17]$. The Lignin peroxidase has the highest redox potential and facilitates attack of both phenolic and non-phenolic structures of recalcitrant compounds, including diazo, triazo, anthraquinone, and triphenylmethane dye structures [17].

\section{Screening for Efficient RB5-Degrading Fungi}

Isolates of white rot fungi can degrade azo dyes, including Bjerkandera adusta [2], Dichomitus squalens [20], Irpex lacteus [22], P. chrysosporium [1], and Pleurotus spp. [26,36]. The current isolates were screened for such potential decolorizing activity toward RB5 by monitoring the conversion of the dark blue RB5 $(100 \mathrm{mg} / \mathrm{L})$ to light yellow products (Table 1). Seven of the 13 isolates from four genera were dye degrades, including Irpex lacteus PBU 0049, Junghuhnia crustacean PBU 0050, Macrohyporia dictyopora PBU 0051, Phanerochaete sordida PBU 0057, Phanerochaete spp. PBU 0056, PBU 0058, and PBU 0059. However,
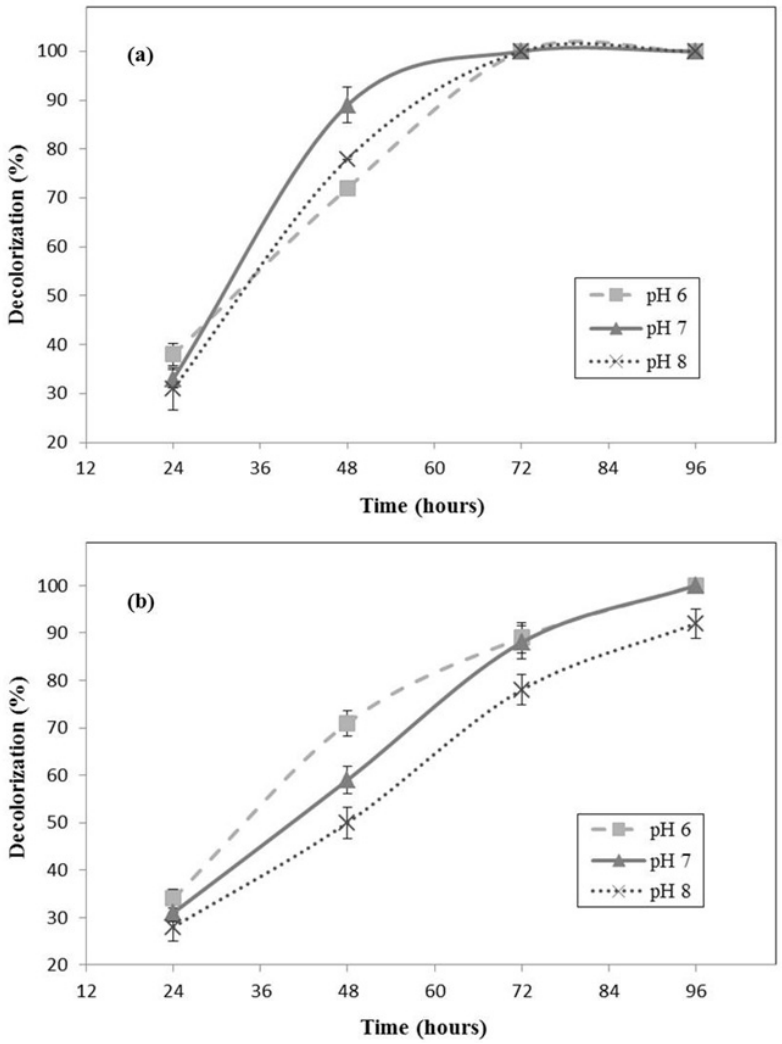

Fig. 1. Effect of $\mathrm{pH}$ on the decoloration of RB5 $(100 \mathrm{mg} / \mathrm{L})$ and polynomial regression equations for $\mathrm{pH} 6,7$, and 8 at $30^{\circ} \mathrm{C}$ with agitation at $150 \mathrm{rpm}$ by (a) P. sordida PBU $0057\left(\mathrm{y}=-0.0148 \mathrm{x}^{2}\right.$ $+2.6625 \mathrm{x}-18.5$; $\mathrm{pH} 6, \mathrm{y}=-0.0204 \mathrm{x}^{2}+3.4021 \mathrm{x}-38.75$; $\left.\mathrm{R}^{2}=0.9999 ; \mathrm{pH} 7, \mathrm{y}=-0.02 \mathrm{x}^{2}+3.80 \mathrm{x}-42.50 ; \mathrm{pH} 8\right)$ and $(\mathrm{b})$ P. chrysosporium ATCC $24725\left(\mathrm{y}=-0.0113 \mathrm{x}^{2}+2.2542 \mathrm{x}-13\right.$; $\mathrm{pH} 6, \mathrm{y}=-0.0069 \mathrm{x}^{2}+1.8167 \mathrm{x}-9.5 ; \mathrm{pH} 7, \mathrm{y}=-0.0035 \mathrm{x}^{2}+$ $1.3333 \mathrm{x}-3$; $\mathrm{pH} 8$ ). Data are mean \pm SD of triple experiments. different species of the same genus could be either positive (Macrohyporia dictyopora PBU 0051) or negative (Macrohyporia sp. PBU 0052) degraders (Table 1). Decoloration by J. crustacea, M. dictyopora, and $P$. tephropora appear as newly reported activities.

The seven positive cultures were further evaluated in liquid medium (100 mg/L RB5). Decoloration ranged from $43-100 \%$ within three days (Table 1). Of these seven isolates, $P$. sordida PBU 0057 had the greatest decolorizing ability. It was slightly more active than the reference $P$. chrysosporium ATCC 24725) yielding complete decoloration (100 mg/L of RB5 in liquid media) within three days of incubation. Adsorption of the dye color into the mycelium was observed in five isolates out of the seven tested fungi, except $P$. sordida PBU 0057 and I. lacteus PBU 0049. The bioadsorption usually occurred at the early stage of the decoloration, resulting in the fast removal of the dye from the culture broth. Dye removal by this mechanism can be temporary since dye residues can be released through hyphal degradation [6, 10]. Some white rot fungi, such as Bjerkandera adusta, could further completely biodegrade the dye inside or outside their mycelia [9]. In the current study, P. sordida
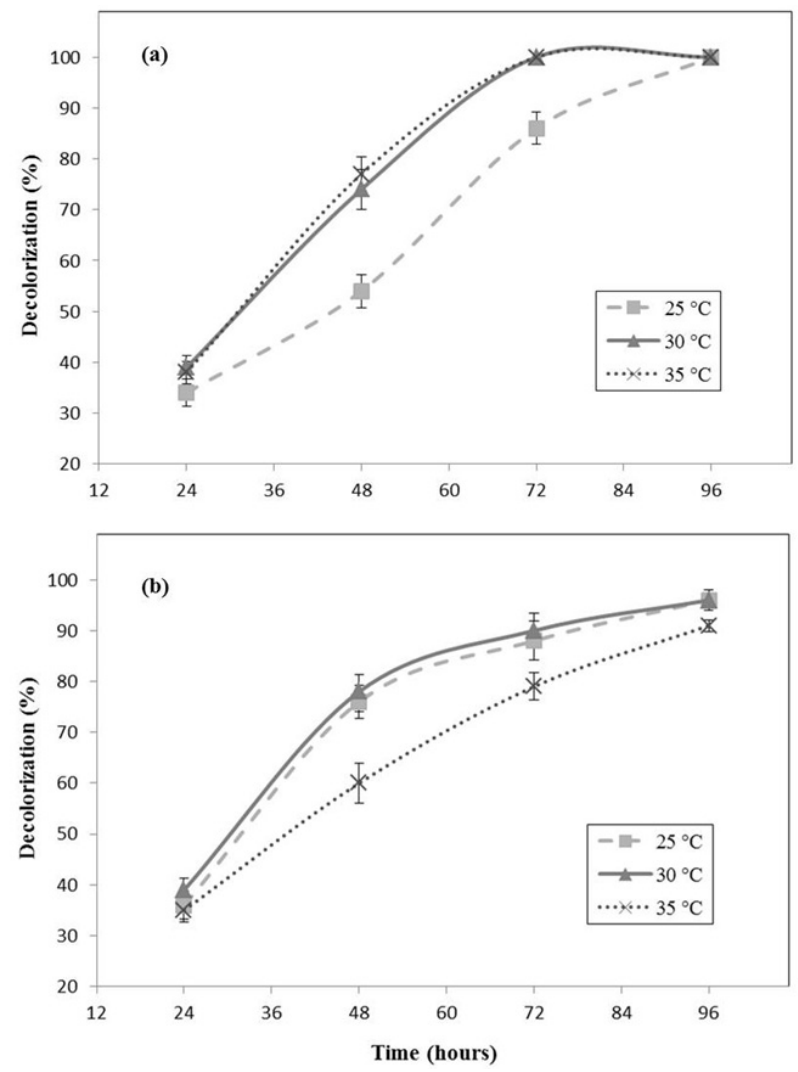

Fig. 2. Effect of temperature on the decoloration of RB5 $(100 \mathrm{mg} / \mathrm{L})$ and polynomial regression equations for $25^{\circ} \mathrm{C}, 30^{\circ} \mathrm{C}$, and $35^{\circ} \mathrm{C}$ at $\mathrm{pH} 7$ with agitation at $150 \mathrm{rpm}$ by (a) P. sordida PBU $0057\left(\mathrm{y}=-0.0026 \mathrm{x}^{2}+1.2708 \mathrm{x}+3.5 ; 25^{\circ} \mathrm{C}, \mathrm{y}=-0.0152 \mathrm{x}^{2}\right.$ $+2.6938 \mathrm{x}-17.75 ; 30^{\circ} \mathrm{C}, \mathrm{y}=-0.0169 \mathrm{x}^{2}+2.9021 \mathrm{x}-22.25$; $\left.35^{\circ} \mathrm{C}\right)$ and (b) P. chrysosporium ATCC $24725\left(\mathrm{y}=-0.0139 \mathrm{x}^{2}\right.$ $+2.4667 \mathrm{x}-14 ; 25^{\circ} \mathrm{C}, \mathrm{y}=-0.0143 \mathrm{x}^{2}+2.4813 \mathrm{x}-11.25 ; 30^{\circ} \mathrm{C}$, $\left.\mathrm{y}=-0.0056 \mathrm{x}^{2}+1.4563 \mathrm{x}+3.25 ; 35^{\circ} \mathrm{C}\right)$. Data are mean $\pm \mathrm{SD}$ of triple experiments. 
PBU 0057 and I. lacteus PBU 0049 efficiently decolorized the dye without evidence of the dye being taken up by the mycelia. Since the decolorizing ability of $P$. sordida PBU 0057 toward RB5 was the greatest among the new isolates and occurred without adsorption, it was selected for further evaluation. Its efficacy was evaluated under varied physicochemical parameters $(\mathrm{pH}$, temperature, agitation, and RB5 concentration) with comparative studies to the reference P. chrysosporium ATCC 24725.

\section{Effects of Physicochemical Culture Conditions on P. sordida PBU 0057}

\section{Effects of pH on Decoloration}

With regard to RB5 decoloration, this azo dye wastewater is usually neutral to alkaline $[3,7]$. However, though fungi grow optimally under weakly acidic conditions, the azo dyes were degraded even in a slightly alkaline $\mathrm{pH}$ range ( $\mathrm{pH} 7$ to 8 ; Fig. 1). P. sordida $\mathrm{PBU}$ 0057 yielded $100 \%$ decoloration in 72 hours over the $\mathrm{pH}$ range (pH 6-8; Fig. 1a), while $P$. chrysosporium reached the maximum (96\%) by 96 hours, though lesser (93\%) at pH 8 (Fig. 1b).
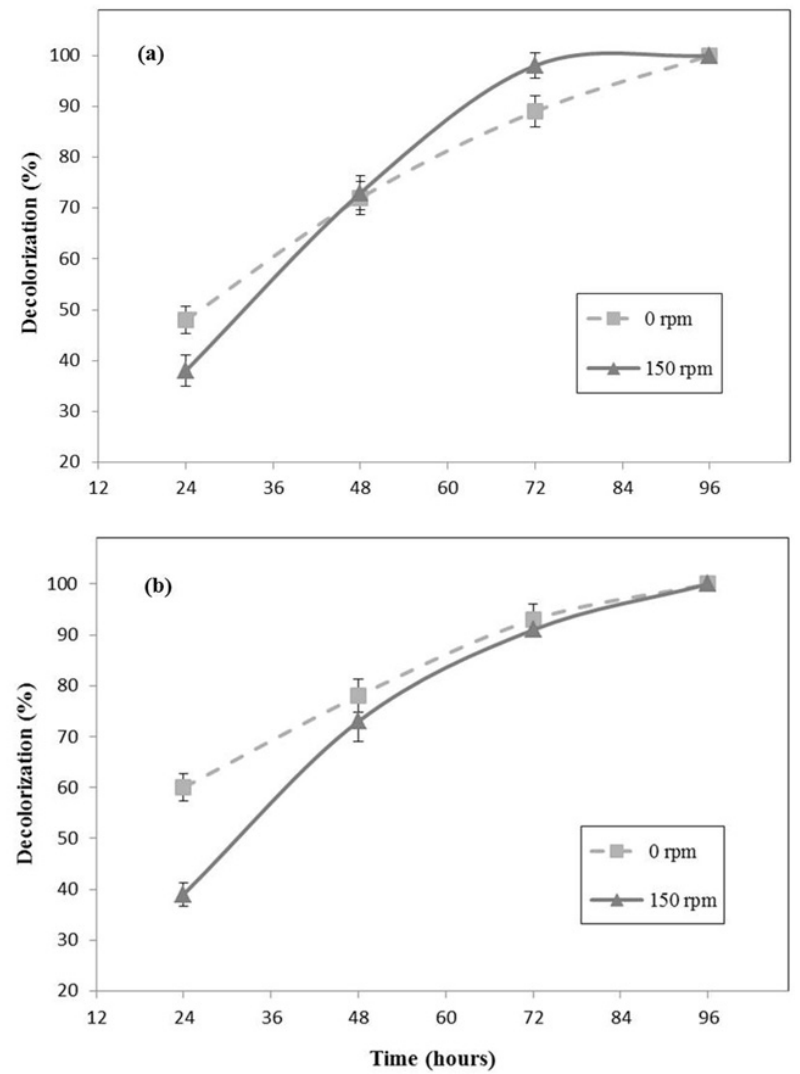

Fig. 3. Effect of agitation on the decoloration of RB5 (100 mg/L) and polynomial regression equations for $0 \mathrm{rpm}$ and $150 \mathrm{rpm}$ at $30^{\circ} \mathrm{C}$ and $\mathrm{pH} 7$ by (a) P. sordida PBU $0057\left(\mathrm{y}=-0.0143 \mathrm{x}^{2}\right.$ $+2.5979 \mathrm{x}-16.75 ; 0 \mathrm{rpm}, \mathrm{y}=-0.0143 \mathrm{x}^{2}+2.5979 \mathrm{x}-16.75$; $150 \mathrm{rpm})$ and (b) P. chrysosporium ATCC $24725\left(\mathrm{y}=-0.0048 \mathrm{x}^{2}\right.$ $+1.1354 \mathrm{x}+35.25 ; 0 \mathrm{rpm}, \mathrm{y}=-0.0109 \mathrm{x}^{2}+2.1396 \mathrm{x}-5.75$; $150 \mathrm{rpm})$. Data are mean \pm SD of triple experiments.

\section{The Effect of Temperature on Decoloration}

The effect of temperature on decoloration was assessed at 25,30 , and $35^{\circ} \mathrm{C}$ (Figs $2 \mathrm{a}, \mathrm{b}$ ). Complete RB5 decoloration by $P$. sordida PBU 0057 occurred by 72 hours at 30 and $35^{\circ} \mathrm{C}$, but was delayed until 96 hours at $25^{\circ} \mathrm{C}$ (Fig. 2a). Overall, the tropical isolates have the advantage of being active at higher temperatures - a practical attribute in tropical wastewater treatment facilities $[21,26]$.

\section{The Effects of Aeration on Decoloration}

Although agitation is probably not practical on a commercial scale such as a holding pond, it might reflect agitation. The effect of aeration on decoloration was addressed by cultures grown with and without agitation (0 or $150 \mathrm{rpm}$ ). The decoloration of RB5 by both $P$. sordida PBU 0057 (100\%) and P. chrysosporium (97\%) was effective in still and shake culture (Figs $3 \mathrm{a}, \mathrm{b}$ ). Comparatively, the efficiency of RB5 decoloration by Pleurotus eryngii F032 [26] was enhanced by agitation while it retarded the activity of $P$. chrysosporium and I. lacteus $[40,41]$. A more detailed study of the effects of aeration appears to be appropriate with the current strains.
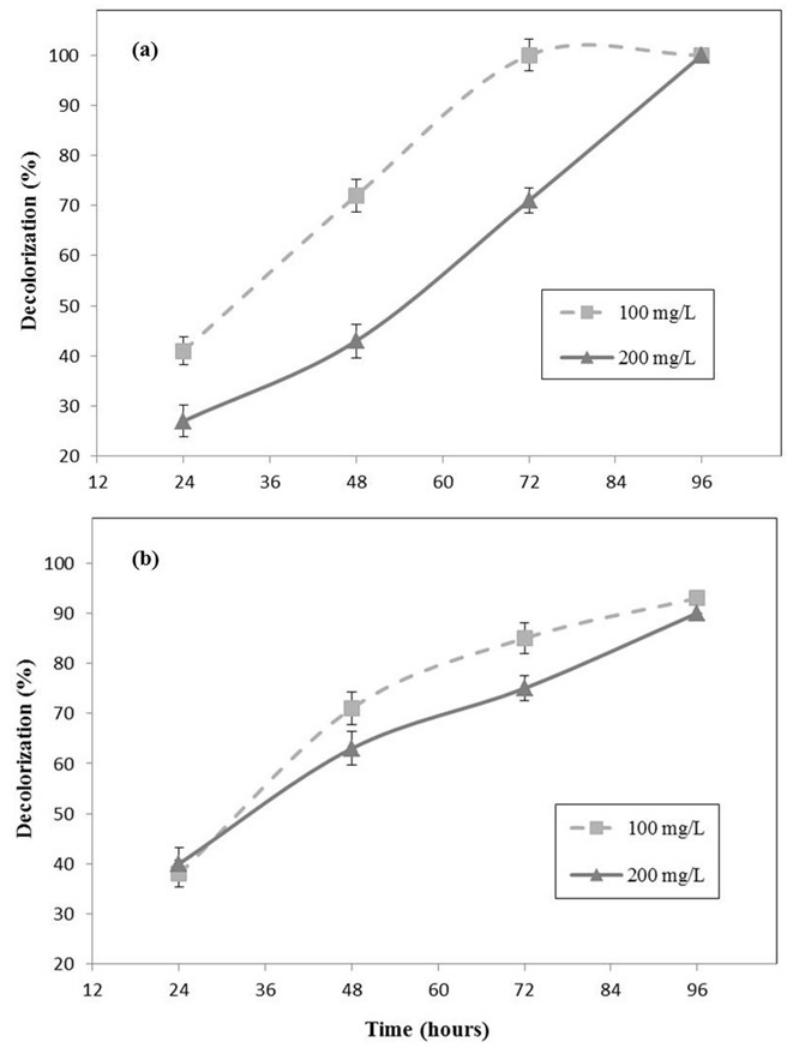

Fig. 4. Effect of RB5 concentration on the decoloration of RB5 and polynomial regression equations for $100 \mathrm{mg} / \mathrm{L}$ and 200 $\mathrm{mg} / \mathrm{L} \mathrm{RB} 5$ at $30^{\circ} \mathrm{C}, \mathrm{pH} 7$ with agitation at $150 \mathrm{rpm}$ by (a) $P$. sordida $\mathrm{PBU} 0057\left(\mathrm{y}=-0.0135 \mathrm{x}^{2}+2.4687 \mathrm{x}-11.75 ; 100 \mathrm{mg} / \mathrm{L}\right.$, $\left.\mathrm{y}=0.0056 \mathrm{x}^{2}+0.3521 \mathrm{x}+14.75 ; 200 \mathrm{mg} / \mathrm{L}\right)$ and (b) $P$. chrysosporium ATCC $24725\left(\mathrm{y}=-0.0109 \mathrm{x}^{2}+2.0479 \mathrm{x}-\right.$ $\left.4.25 ; 100 \mathrm{mg} / \mathrm{L}, \mathrm{y}=-0.0035 \mathrm{x}^{2}+1.0917 \mathrm{x}+16.5 ; 200 \mathrm{mg} / \mathrm{L}\right)$. Data are mean $\pm \mathrm{SD}$ of triple experiments. 
Table 2. Lignin-modifying enzyme production of $P$. sordida PBU 0057 and $P$. chrysosporium ATCC 24725 when cultured in the presence of RB5 dye.

\begin{tabular}{|c|c|c|c|c|c|}
\hline & \multirow{2}{*}{ Enzyme activity } & \multicolumn{4}{|c|}{ Day $(\mathrm{U} / \mathrm{mL})$} \\
\hline & & 1 & 2 & 3 & 4 \\
\hline \multirow{3}{*}{ P. sordida PBU 0057} & Laccase & $0.34 \pm 0.02$ & $0.36 \pm 0.02$ & $0.39 \pm 0.03$ & $0.44 \pm 0.03$ \\
\hline & Lignin peroxidase & $0.33 \pm 0.05$ & $0.12 \pm 0.05$ & $0.11 \pm 0.02$ & $0.07 \pm 0.02$ \\
\hline & Manganese peroxidase & ND & ND & ND & ND \\
\hline \multirow{3}{*}{$\begin{array}{l}\text { P. chrysosporium } \\
\text { ATCC } 24725\end{array}$} & Laccase & $0.10 \pm 0.01$ & $0.14 \pm 0.02$ & $0.17 \pm 0.02$ & $0.21 \pm 0.02$ \\
\hline & Lignin peroxidase & $0.28 \pm 0.05$ & $0.18 \pm 0.05$ & $0.15 \pm 0.03$ & $0.11 \pm 0.03$ \\
\hline & Manganese peroxidase & $0.21 \pm 0.03$ & $0.27 \pm 0.04$ & $0.29 \pm 0.04$ & $0.31 \pm 0.03$ \\
\hline
\end{tabular}

Values are the mean $\pm \mathrm{SD}$ of triple experiments $\quad \mathrm{ND}=$ Not detectable

\section{The Effect of Initial Dye Concentration on Decoloration}

Dye concentration was addressed. P. sordida PBU 0057 completely decolorized RB5 (100 mg/L) by 72 hours and it was slightly slower at the higher concentration (200 mg/L) (Fig. 4a). P. chrysosporium was effective at the same concentrations (Fig. 4b). The concentrations of azo dyes in waste effluents are in the range of 50 to $200 \mathrm{mg} / \mathrm{L}$ [11], and thus both strains are effective in these practical ranges.

\section{Decoloration Rate at $80 \%$ Decoloration (T80) of $R B 5$}

The decoloration efficacy of each treatment was compared on a basis of the time required for $80 \%$ decoloration (T80). The hours at T80 were calculated from polynomial regression equations from Figs 1-4 (Table 4). At T80, the decoloration rate of $P$. sordida $\mathrm{PBU} 0057$ was found to be faster than $P$. chrysosporium at all $\mathrm{pHs}, 30^{\circ} \mathrm{C}$, $35^{\circ} \mathrm{C}$, with agitation and at $100 \mathrm{mg} / \mathrm{l}$ of RB5 (Table 4). The results suggested that $\mathrm{pH}$, temperature, agitation, and dye concentration had effects upon the rate of decoloration of both strains at $\mathrm{T} 80$.

\section{Activity of Lignin-Modifying Enzymes during Decoloration}

On growth in the presence of RB5, laccase and lignin peroxidase were detected in the culture fluid of $P$. sordida PBU 0057 (Table 2), while manganese peroxidase was additionally found during the culture of $P$. chrysosporium. Over four days of culture, laccase activity by $P$. sordida PBU 0057 increased gradually, and this was paralleled by manganese peroxidase and laccase activities of $P$. chrysosporium. In contrast, lignin peroxidase of both fungi was only detected early on with maximum levels on day 2 (Table 2). For P. sordida PBU 0057, only laccase activity appeared to correlate with decoloration, but the potential enhancement of decoloration may involve lignin peroxidase in providing the variety of intermediates which are further metabolized by laccase or manganese peroxidase [17]. During the RB5 decoloration, lignin peroxidase activity could be detected only in the early period of culture, whereas laccase activity correlated with decoloration (Table 4). Lignin peroxidase and laccase have been linked to the decoloration of azo dyes by white rot fungi [26], but the decoloration of RB5 by P. sordida PBU 0057 perhaps occurred mainly through the activity of laccase. However, such a correlation on its own does not establish the role for laccase, but for the potential enhancing involvement of lignin peroxidase in providing the lignin peroxidase-produced metabolites that were further metabolized by laccase $[12,17]$. Overall, an optimal dye decoloration and detoxicfication process with microbes that produce lignin peroxidase in the aggregate enzyme systems are preferable.

\section{RB5 Degradation}

Disruption of the azo dye structure results in loss of its color [42]. RB5 has a maximum absorbance at $597 \mathrm{~nm}$ (Fig. 5). To verify that RB5 decoloration by $P$. sordida PBU 0057 corresponded with degradation of the dye as quantified by spectrophotometry and HPLC. The UV-visible light spectrum of $P$. sordida PBU 0057 culture

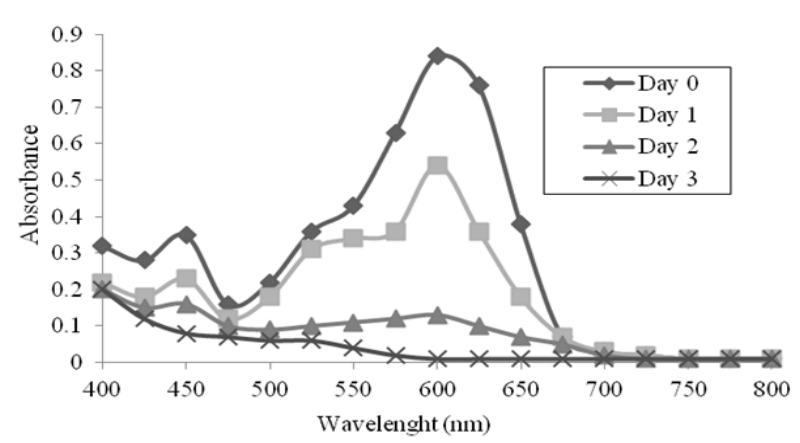

Fig. 5. The UV-vis spectrum of culture fluid containing RB5 after treatment with $P$. sordida $\mathrm{PBU} 0057$ (comparison from day $0,1,2$, and 3 days at $\mathrm{pH} 7$ and $35^{\circ} \mathrm{C}$; spectra are representative of two independent experiments). 

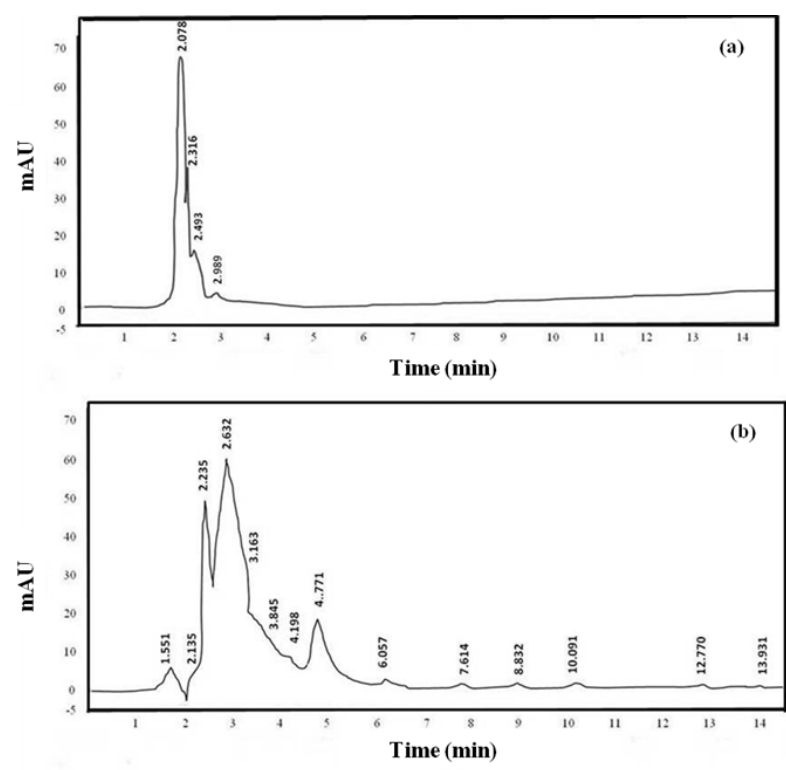

Fig. 6. HPLC profile of (a) RB5 (200 mg/L) and (b) the degraded RB5 after complete decoloration by P. sordida PBU 0057 (RB5 at $200 \mathrm{mg} / \mathrm{L}$ treated for $4 \mathrm{~d}$ at $30^{\circ} \mathrm{C}, \mathrm{pH} 7$ with agitation at $150 \mathrm{rpm})$. Profiles are representative of two independent experiments.

fluid containing RB5 showed the $597 \mathrm{~nm}$ absorption peak that decreased over time and became undetectable after three days (Fig. 5). The complete disappearance of the major peak of RB5 suggested that $P$. sordida PBU 0057 has broken the azo bonds. HPLC analysis similarly showed the disappearance of the major RB5 peak (Figs 6 $\mathrm{a}, \mathrm{b})$ and the formation of a broad range of different peaks with longer retention times. Degradation of RB5 by $P$. chrysosporium [40] and of reactive Levafix Blue by Irpex lacteus [21] has been based on spectrophotometric and HPLC analyses. Degradation of RB5 by $P$. sordida PBU 0057 is clearly indicated (Figs 5, 6).

\section{Phytotoxicity of RB5 Degradation Products}

Plants are sensitive indicators of remediation byproducts showing either inhibition or stimulation (induction)
Table 4 . Hours required to reach $80 \%$ decoloration (T80) of RB5 as a factor of $\mathrm{pH}$, temperature, shaking, and concentration, which are calculated with polynomial regression equations from Figs $1-4$.

\begin{tabular}{|c|c|c|c|}
\hline \multirow{4}{*}{ Factors } & & \multicolumn{2}{|c|}{ T80 (Hour) } \\
\cline { 2 - 4 } & & $\begin{array}{c}\text { P. sordida } \\
\text { PBU 0057 }\end{array}$ & $\begin{array}{c}\text { P. chrysosporium } \\
\text { ATCC 24725 }\end{array}$ \\
\hline \multirow{4}{*}{$\mathrm{pH}$} & 6 & 52 & 58 \\
\cline { 2 - 4 } & 7 & 50 & 66 \\
\cline { 2 - 4 } & 8 & 41 & 78 \\
\hline \multirow{4}{*}{$\begin{array}{c}\text { Temperature } \\
\left({ }^{\circ} \mathrm{C}\right)\end{array}$} & 25 & 76 & 55 \\
\cline { 2 - 4 } & 30 & 51 & 53 \\
\cline { 2 - 4 } & 35 & 50 & 75 \\
\hline \multirow{3}{*}{\begin{tabular}{c} 
Shaking (rpm) \\
\cline { 2 - 4 }
\end{tabular}} & 0 & 57 & 50 \\
\hline $\begin{array}{c}\text { Concentration } \\
(\mathrm{mg} / \mathrm{L})\end{array}$ & 150 & 51 & 56 \\
\cline { 2 - 4 } & 200 & 80 & 61 \\
\hline
\end{tabular}

of plant growth and development [37]. Phytotoxicity of the RB5 products from $P$. sordida $\mathrm{PBU} 0057$ was assessed by analysis of their effect on seed germination and seedling development [5, 37] using three dye-sensitive plants: sorghum, corn, and red kidney bean [5] (Table 3). Seed germination percentages of plants after soaking with the decolorized dye metabolites ranged from $90-100 \%$ and showed no significant difference with the controls (seeds soaked in water; 100\%) (Table 3). The RB5 degradation products were not toxic(90-100\% germination) in comparison to the original dye (germination over 80 , 40 , and $65 \%$ ). Likewise for seedling growth, in terms of shoot and root length, the seeds soaked with the degraded dye products exhibited no growth inhibition of the three plants in contrast to the marked inhibition of seed response when treated directly with the dye (Table 3). An exception was shoot length of Phaseolus mungo, which was not significantly different in all treatments.

Table 3. Phytotoxicity of RB5 and its degradation products toward Phaseolus vulgaris L., Sorghum bicolor L, and Zea mays L.

\begin{tabular}{|c|c|c|c|c|c|c|c|c|c|}
\hline \multirow[b]{2}{*}{ Parameters } & \multicolumn{3}{|c|}{ Phaseolus vulgaris L. } & \multicolumn{3}{|c|}{ Sorghum bicolor L. } & \multicolumn{3}{|c|}{ Zea mays L. } \\
\hline & Water & $\mathrm{RB}^{*}$ & $\begin{array}{l}\text { Extracted } \\
\text { metabolite }^{* *}\end{array}$ & Water & $\mathrm{RB}^{*}$ & $\begin{array}{l}\text { Extracted } \\
\text { metabolite }^{* *}\end{array}$ & Water & $\mathrm{RB}^{*}$ & $\begin{array}{l}\text { Extracted } \\
\text { metabolite }^{* *}\end{array}$ \\
\hline Germination (\%) & $100^{\mathrm{a}}$ & $80^{\mathrm{b}}$ & $100^{\mathrm{a}}$ & $100^{\mathrm{a}}$ & $40^{\mathrm{b}}$ & $90^{\mathrm{a}}$ & $100^{\mathrm{a}}$ & $65^{\mathrm{b}}$ & $90^{\mathrm{a}}$ \\
\hline Shoot length $(\mathrm{cm})$ & $1.4 \pm 0.3^{\mathrm{a}}$ & $1.2 \pm 0.4^{\mathrm{a}}$ & $1.3 \pm 0.4^{\mathrm{a}}$ & $0.5 \pm 0.2^{\mathrm{a}}$ & $0.1 \pm 0.2^{\mathrm{b}}$ & $0.7 \pm 0.4^{\mathrm{a}}$ & $1.3 \pm 0.4^{\mathrm{a}}$ & $0.7 \pm 0.1^{\mathrm{b}}$ & $1.5 \pm 0.2^{\mathrm{a}}$ \\
\hline Root length (cm) & $3.5 \pm 0.3^{\mathrm{a}}$ & $2.5 \pm 0.6^{\mathrm{b}}$ & $3.9 \pm 0.4^{\mathrm{a}}$ & $2.0 \pm 0.4^{\mathrm{a}}$ & $0.7 \pm 0.4^{\mathrm{b}}$ & $2.4 \pm 0.6^{\mathrm{a}}$ & $4.3 \pm 0.6^{\mathrm{a}}$ & $2.9 \pm 0.4^{\mathrm{b}}$ & $4.6 \pm 0.6^{\mathrm{a}}$ \\
\hline
\end{tabular}

* Seeds soaked in RB5 (200 mg/L).

** Seeds soaked in degradation products of RB5 (200 mg/L) from P. sordida PBU 0057 (cultured at $30{ }^{\circ} \mathrm{C} ; 150 \mathrm{rpm}$ at $\mathrm{pH} 7$ for 4 days to complete decoloration).

Values are the mean \pm SD of five replicates. Values followed by letters $(a, b)$ in the same row of each plant are significantly different from the control (seeds soaked with water) at $\mathrm{p}<0.05$ by one-way analysis of variance (ANOVA) with Dunnett's test. 
In overview, the phytotoxicity of RB5 was eliminated after treatment with $P$. sordida PBU 0057. Fungal detoxification of the azo dyes has been noted, including navy blue HER degradation after treatment with Trichosporon beigelii NCIM-3326, which relieved the inhibition of seed germination of P. mungo and Sorghum bicolor [43]. Also, degradation products of azo dye, acid red 27 after treatment with Armillaria sp. F022 showed no growth inhibition toward $S$. vulgare and Triticum aestivum [44]. The detoxification of the recalcitrant azo dyes by $P$. sordida PBU 0057 can potentially be developed for useful detoxification environmental protocols.

\section{Conclusions}

The biological detoxification of synthetic dye wastes by mineralization can potentially be achieved using white rot fungi. Thirteen isolates of resupinate white rot fungi from across Thailand were recovered and their degradative action towards the azo dye, reactive black 5 (RB5), was assessed. Seven isolates from this basidiomycete group were capable of decolorizing the dye. The new strain Phanerochaete sordida PBU 0057 was slightly faster and more efficient in its decoloration and detoxification than the reference strain P. chrysosporium ATCC 24725. The decoloration was a result of biodegradation and not due to biosorption. Decoloration occurred under a range of physicochemical conditions reflecting practical levels in dye wastewater treatment. The lack of phytotoxicity of the biodegradation products from RB5 produced by $P$. sordida PBU 0057 is the most positive finding in regard to bioremediation potential in treatment of dye wastes. Decoloration reported for the first time of $J$. crustacea, $M$. dictyopora, and $P$. tephropora augurs well for further analysis of the relatively unstudied resupinate group to uncover their further capabilities.

\section{Acknowledgements}

The authors thank the Royal Golden Jubilee (RGJ) Ph.D. grant 4.S.CU/49/Q.1 contract number PHD/0162/2549, the Thailand Research Fund, the Eveleigh-Fenton fund, and the Research Center for Thermotolerant Microbial Resources (RCTMR) in Yamaguchi University, including the JSPS, Core-to-Core Program for the establishment of an international research core for new bio-research fields with microbes from tropical areas for financial support. This research also was supported by the Department of Plant Biology and Pathology (Rutgers University), the National Museum of Natural Science (Taiwan), the Plant Biomass Utilization Research Unit (Chulalongkorn University), and the Biological Sciences Program, Department of Botany, Faculty of Science, Chulalongkorn University - all of which is gratefully acknowledged.

\section{References}

1. KUHAD R., SOOD C., TRIPATHI N. K. K., SINGH A., WARD O. P. Developments in microbial methods for the treatment of dye effluents. Adv. Appl. Microbiol. 5 6, 185, 2004.

2. FU Y., VIJARAGHAVAN T. Fungal decolorization of dye wastewaters. Biores. Technol. 79, 251, 2001.

3. FORGACS E., CSERHATI T., OROS G. Removal of synthetic dyes from waste waters: a review. Environ. Int. 30, 953, 2004.

4. LU K., ZHANG X. L., ZHAO Y. L., WU Z. L. Removal of color from textile dyeing wastewater by foam separation., $J$. Hazard. Mater. 182, 928, 2010.

5. ARAUJO A.S.F., MONTEIRO R.T.R. Plant bioassays to assess toxicity of textile sludge compost. Scientia Agricola. Piracicaba, Brazil, 62 (3), 286, 2005.

6. ALI H. Biodegradation of synthetic dyes-A review. Water Air Soil Poll. 213, 251. 2010.

7. VIJAYARAGHAVAN J., BASHA S.J.S., JEGAN J. A review on efficacious methods to decolorize reactive azo dye. J. Urban. Env. Eng. 7, 30, 2013.

8. BARDI L., MARZONA M. in The Handbook of Environmental Chemistry: Factors affecting the complete mineralization of azo dyes (Ed.: H. A. Erkurt). SpringerVerlag, Berlin, Germany, 195, 2010.

9. ANASTASI A., PARATO B., SPINA F., TIGINA V., PRIGIONE V., VARESE G.C. Decolourisation and detoxification in fungal treatment of textile wastewaters from dying processes. N. Biotechnol. 29, 38, 2011.

10. DAWEN G., LINA D., JIAOLING Y., WEI M. W., HONG L. A critical review of the application of white rot fungus to environmental pollution control. Crit. Rev. Biotechnol. 30, 70, 2010.

11. KAUSHIK P., MALIK A. Fungal dye decolorization: Recent advances and future potential. Environ. Int. 35, 127, 2009.

12. JOSHNI T.C., KALIDASS S. Enzymatic degradation of azo Dyes: A review. Int. J. Environ. Sci. Te. 1, 1250, 2011.

13. HATAKKA A., HAMMEL K.E. in Mycota Industrial Applications: Fungal biodegradation of lignocelluloses (Ed.: M. Hofrichter). Springer-Verlag, Berlin, Germany, 319, 2010.

14. VOLK T. Polypore primer: An introduction of the characters used to identify poroid wood decay fungi. McIlvainea, 14, 74, 2000.

15. HIBBETT D.S., BINDER M. Evolution of complex fruitingbody morphologies in homobasidiomycetes. Proc. Biol. Sci. 269, 1963, 2002.

16. KIRK T.K., HIGUCHI T., CHANG H. in Lignin biodegradation: microbiology, chemistry, and potential applications vol II: Lignin biodegradation: Summary and perspectives (Eds.: T. K. Kirk, T. Higuchi, H. Chang). CRC Press, Boca Raton, Florida, 235, 1980.

17. PAVKO A. in Waste Water-Treatment and Reutilization: Fungal decolourization and degradation of synthetic dyes, some chemical engineering aspects (Ed.: F. S. Garcia). EINSCHLAG, Rijeka, Intech, Croatia, 65, 2011.

18. SINGH S., PAKSHIRAJAN K. Enzyme activities and decolourization of single and mixed azo dyes by the white rot fungus Phanerochaete chrysosporium. Int. Biodeter. Biodegr. 64, 146, 2010.

19. TIEN M., KIRK T.K. Lignin peroxidase of Phanerochaete chrysosporium. Method Enzymol. 161, 238, 1988. 
20. EICHLEROVÁ I., LADISLAV H., FRANTIŠEK N. Synthetic dye decolorization capacity of white rot fungus Dichomitus squalens. Biores. Technol. 97, 2153, 2007.

21. KALPANA D., VELMURUGAN N., SHIM J.H., OH B.T., SENTHIL K., LE Y.S. Biodecolorization and biodegradation of reactive Levafix Blue E-RA granulate dye by the white rot fungus Irpex lacteus. J. Environ. Manage. 111, 142, 2012.

22. NOVOTNY C., CAJTHAML T., SVOBODOVA K., SUSLA M., SASEK V. Irpex lacteus: a white rot fungus with biotechnological potential-review. Folia Micrologica, 54, 375, 2009.

23. MUELLER M.G., BILLS F.J., FOSTER S.M. in Inventorying and Monitoring Methods: Biodiversity of Fungi. Elsevier Academic Press, New York, 128, 2004.

24. CHOEYKLIN R., HATTORI T., JONES E.B.G. A checklist of aphyllophoraceous fungi in Thailand: Part I. New records. Mycosphere, 2, 167, 2011.

25. VAITHANOMSAT P., SANGNAM A., BOONPRATUANG T., CHOEYKLIN R., PROMKIAM-ON P., CHUNTRANULUCK S., KREETACHAT T. Wood degradation and optimized laccase production by resupinate white rot fungi in Northern Thailand. Bioresources, 8, 6342, 2013.

26. HADIBARATA T., ADNA L.A., YUSOFF A. R.M., YUNIARTO A., RUBIYATNO, ZU M.M.F.A., KHUDHAIR A.B., TEH Z.C., NASER M.A. Microbial decolorization of an azo dye reactive black 5 using white rot fungus, Pleurotus eryngii F032. Water Air Soil Poll. 224, 1595, 2013.

27. WU S.H. The Corticiaceae (Basidiomycetes) subfamilies Phlebioideae, Phanerochaetoideae and Hyphodermoideae in Taiwan. Acta Botanica Fennica. The Finnish Botanical Publishing Board, Helsinki, 142, 1990.

28. DAVIS L.G., DIBNER M.D., BATTEY J.F. Basic Methods in Molecular Biology. Elsevier, New York, USA, 42, 1986.

29. WHITE T.J., BRUNS T., LEE S., TAYLOR J. in PCR Protocols: a guide to methods and applications, Amplification and direct sequencing of fungal ribosomal RNA genes for phylogenetics (Eds.: M. A. Innis, D. H. Gelfand, J. J. Sninsky, T. J. White). Academic Press, New York, USA, 315, 1990.

30. POINTING S.B. Qualitative methods for the determination of lignocellulolytic enzyme production by tropical fungi. Fungal Divers. 2, 17, 1999.

31. WOLFENDEN B.S., WILSON R.I. Radical-cations as reference chromogens in kinetic studies of one-electron transfer reactions. J. Chem. Soc. Perk. T. II. 11, 805, 1982.

32. ORTH A. B., ROYSE D., TIEN M. Ubiquity of lignindegrading peroxidases among various wood-degrading fungi, Appl. Environ. Microbiol. 59 (12), 4017, 1993.
33. ARCHIBALD F.S. A new assay for lignin-type peroxidases employing the dye azure B. Appl. Environ. Microbiol. 58 (9), 3110, 1992.

34. DIWANIYAN S., KHARB D., RAGHUKUMAR C., KUHAD R.C. Decolorization of synthetic dyes and textile effluents by basidiomycetous fungi. Water Air Soil Poll. 210, 409, 2010.

35. MARTINEZ M.J., RUIZ-DUENAS F.J., CUILLEN F., MARTINEZ A. T. Purification and catalytic properties of two manganese peroxidase isoenzymes from Pleurotus eryngii. Eur. J. Biochem. 237, 424, 1996.

36. ZHAO X., I. HARDIN R. HPLC and spectrophotometric analysis of biodegradation of azo dyes by Pleurotus ostreatus. Dyes Pigm.73, 322, 2007.

37. CRUZ J.M., LOPES P.R.M., MONTAGNOLLI R.N., TAMADA I.S., SILVA N.M. M.G., BIDOIA E.D. Toxicity assessment of contaminated soil using seeds as bioindicators. J. Appl. Biotechnol. 1, 1, 2013.

38. SARATALE R.G., SARATALE G.D., CHANG J.S., GOVINDWAR S.P. Ecofriendly degradation of sulfonated diazo dye C.I Reactive Green 19A using Micrococcus glutamicus NCIM-2168. Biores. Technol. 100, 3897, 2009.

39. WU H., PRATLEY J., LEMERLE D., AN M., LIU D.L. Autotoxicity of wheat (Triticum aestivum L.) as determined by laboratory bioassays. Plant Soil, 296, 85, 2007.

40. ENAYATIZAMIR N., TABANDEH F., RODRÍGUEZCOUTO S., YAKHCHALI B., ALIKHANI H.A., MOHAMMADI L. Biodegradation pathway and detoxification of the diazo dye Reactive Black 5 by Phanerochaete chrysosporium. Biores. Technol. 102, 10359, 2011.

41. SVOBODOVA K., ERBANOVA P., SKLENAR J., NOVOTNY C. The role of Mn-dependent peroxidases in dye decolorization by static and agitated cultures of Irpex lacteus. Folia Microbiol. 51, 573, 2006.

42. GUTIERREZ L.V.G., ALATORRE G.G., SILVA E.M.E. Proposed pathways for the reduction of a reactive azo dye in an anaerobic fixed bed reactor. World J. Microbiol. Biotechnol. 25, 415, 2009.

43. SARATALE R.G., SARATALE G.D., CHANG J.S., GOVINDWAR S.P. Decolorization and biodegradation of textile dye Navy blue HER by Trichosporon beigelii NCIM-3326. J. Hazard. Mater. 166, 1421, 2009.

44. ADNAN L.A., SATHISHKUMAR P., HADIBARATA T. Biodegradation pathway of Acid Red 27 by white rot fungus Armillaria sp. F022 and phytotoxicity evaluation. Clean-Soil Air Water, 25, 373-382, 2015. 